\title{
New protocols to assess the environmental impact of pests in the EPPO decision-support scheme for pest risk analysis*
}

\author{
M. Kenis ${ }^{1}$, S. Bacher ${ }^{2}$, R. H. A. Baker ${ }^{3}$, E. Branquart4 ${ }^{4}$ S. Brunel ${ }^{5}$, J. Holt6, P. E. Hulme, \\ A. MacLeod ${ }^{3}$, J. Pergl ${ }^{8}$, F. Petter ${ }^{5}$, P. Pyšek 8,9 , G. Schrader ${ }^{10}$, A. Sissons ${ }^{11}$, U. Starfinger ${ }^{10}$ \\ and U. Schaffner ${ }^{1}$ \\ ${ }^{1}$ CABI Europe-Switzerland, 1 Rue des Grillons, 2800 Delémont (Switzerland); e-mail: m.kenis@cabi.org \\ ${ }^{2}$ University of Fribourg, 6 Chemin du Musée, 1700 Fribourg (Switzerland) \\ ${ }^{3}$ Food and Environment Research Agency, Sand Hutton, York YO41 1LZ (UK) \\ ${ }^{4}$ Belgian Biodiversity Platform, Département de l'Etude du Milieu Naturel et Agricole, Avenue Marechal Juin 23, 5030 Gembloux (Belgium) \\ ${ }^{5}$ European and Mediterranean Plant Protection Organization, 21 Bld Richard Lenoir, 75011 Paris, (France) \\ ${ }^{6}$ Centre for Environmental Policy, Imperial College London, Silwood Park, Ascot SL5 7PY (UK) \\ ${ }^{7}$ The Bio-Protection Research Centre, Lincoln University, PO Box 84, Lincoln, Canterbury (New Zealand) \\ 8Institute of Botany, Academy of Sciences of the Czech Republic, Zámek 1, Pruihonice, 25243 (Czech Republic) \\ ${ }^{9}$ Department of Ecology, Faculty of Science, Charles University in Prague, Viničná 7, 12843 (Czech Republic) \\ 10Julius Kühn Institut, Federal Research Centre for Cultivated Plants, Institute for National and International Plant Health, Messeweg, \\ 11/12, 38104 Braunschweig (Germany) \\ ${ }^{11}$ Andrea Sissons, Canadian Food Inspection Agency, 1400 Merivale Road, Ottawa ON, K1A OY9 (Canada)
}

\begin{abstract}
Assessing the potential environmental impact of alien plants and plant pests is notoriously difficult. New protocols have been developed in the framework of the EC project PRATIQUE to provide guidance on environmental impact assessment in the EPPO pest risk analysis (PRA) decisionsupport scheme and enhance consistency between risk assessors and risk ratings for different pests. A set of questions with rating guidance and examples is provided, and individual scores are summarized into final scores, using a hierarchy of risk matrices, to assess current and potential environmental impacts. Two separate protocols are available: for alien plants and for other pests. These protocols could also be used to assess environmental impact in other PRA schemes as well as to assign alien species to regional black lists or to prioritize species for management decisions.
\end{abstract}

\section{Introduction}

All pest risk analysis (PRA) procedures that follow the recommendations of the International Standard for Phytosanitary Measure (ISPM 11) Pest risk analysis for quarantine pests, including analysis of environmental risks and living modified organisms (FAO, 2004) and ISPM 2 Framework for pest risk analysis (FAO, 2007) include, as part of the evaluation of the consequences of an introduction and establishment of a species, the assessment and prediction of the environmental impact of the target species, together with its economic and social impacts (e.g. USDA-APHIS, 2000; Biosecurity New Zealand, 2006; Biosecurity Australia, 2007; EPPO, 2011). Experts are usually asked to assess both the current impact in the area of present occurrence and the potential impact in the PRA area, using all available data. However, in contrast to the economic impact for which standard assessment methods exist and are used (Soliman et al., 2010), there is no standard and easily applicable method for assessing the current and potential environmental impacts of a plant pest.

*This paper is an outcome of PRATIQUE (Enhancements of Pest Risk Analysis Techniques) a research project funded by the European Union under its $7^{\text {th }}$ Framework Programme.
The complexity and the variety of mechanisms involved in the environmental impact of alien invertebrates and pathogens (Desprez-Loustau et al., 2007; Kenis et al., 2009) as well as alien plants (Vilà et al., 2011) requires that each taxon is studied separately, usually through long and time-consuming field or laboratory studies. These are usually not possible within the framework and budget of a PRA, which aims to take a quick decision with the available information on whether a species or a commodity represents a risk. Thus, the assessment of the potential environmental impact of a pest in an area under assessment (PRA area) relies almost exclusively on expert judgement. In contrast to invertebrates and pathogens, several weed risk assessment (WRA) schemes already exist and are applied worldwide, with some success (e.g. Pheloung et al., 1999; Williams et al., 2002; Daehler et al., 2004; Gordon et al., 2010). However, in general, the structure of these WRA schemes is different from the classical PRA (i.e. they do not necessarily comply with ISPM 11) and their objective is also different because, in most cases, the goal is to assess the potential 'invasiveness' (as defined by Richardson et al., 2000) of a plant already present in a region, or suggested for introduction for ornamental or agricultural purposes and having elements that are not generic (i.e. specifically related to the area of invasion). Although it is generally assumed that 
environmental impact and invasiveness are closely related, Ricciardi \& Cohen (2007) showed that the correlation is questionable.

\section{Environmental impact assessment in the EPPO PRA decision-support scheme}

In the EPPO PRA decision-support scheme, which is the most commonly used PRA scheme in Europe and other EPPO countries, the questions on environmental impact are part of the section 'Assessment of potential economic consequences' because international phytosanitary standards consider environmental damage to be an economic consequence (FAO, 2010). However, in this scheme, questions regarding environmental impacts are separated from those that relate solely to economic and social impacts.

In the version that was used until 2011 (EPPO, 2007), the two questions specifically referring to environmental impact were: (Q2.5) 'How important is environmental damage caused by the pest within its current area of distribution?' and (Q2.6) 'How important is the environmental damage likely to be in the PRA area?' For each question, experts were asked to choose between five qualitative scores (e.g. minimal, minor, moderate, major, massive) and three levels of uncertainty (low, medium, high), and were also requested to provide a justification backed up with references. An assessment of the potential consequences (economic, environmental, social) was also requested. During the review of the EPPO scheme in the EU-funded project PRATIQUE (Enhancements of Pest Risk Analysis Techniques; Baker et al., 2009), several issues related to these two questions were identified, as follows.

(1) There was no guidance on how to score the actual and potential environmental impact and no specified mechanism to combine scores of the impact section, leading to low consistency.

(2) The assessment of environmental impact in the EPPO scheme started with a question on the impact within the current area of distribution of the pest. This is appropriate because the fact that a pest causes environmental concern elsewhere is recognized as the best indicator of a potential impact in the PRA area (Williamson, 1996). However, there was no information on how this question may help answer the key question on potential impact in the PRA area. Furthermore, the first question on current impact was relevant mainly if the pest is already invasive in other regions, because the environmental impact of a native species in an ecosystem in which it has evolved is an ambiguous concept. Furthermore, even if the target pest is already invasive elsewhere, the likelihood that its environmental effect has been properly studied is very low, particularly for invertebrates and pathogens (Desprez-Loustau et al., 2007; Kenis et al., 2009). For many cases where the environmental impact has never been studied, there is no guidance on how to assess the possibility that an impact occurs, or will occur. In these situations, the experts will have the greatest difficulty in answering questions on the current and potential environmental impact.
(3) The two parallel questions gave the impression that they could be answered in the same way, using the same indicators. However, assessing current impact is much easier and can be done with much more precision than predicting potential impact. Types of environmental impact that are particularly difficult to predict include impacts on ecosystem functions and services, and indirect impacts on biodiversity, for example through competition for resources, apparent competition or intraguild predation (Levine et al., 2003; Kenis et al., 2009).

(4) The EPPO scheme has been developed to assess the risk posed by alien plant pests (i.e. alien invertebrates and pathogens harming plants), but is now also used to assess alien pest plants (i.e. all alien plants considered as weeds for agriculture and the environment, including water weeds). Impact mechanisms in these two categories are very different (Parker et al., 1999; Vilà et al., 2010) and, thus, the evaluation of their environmental impact may require different questions and indicators.

\section{A new protocol to assess environmental impact}

In the project PRATIQUE, the approach to assessing the environmental impact of alien plant pests and plants within the EPPO PRA scheme was revised. The two questions relating to environmental impacts remain essentially the same, but are answered by a set of sub-questions, covering the various different aspects of environmental impacts. For each sub-question, rating guidance is provided as well as examples. Rating systems are presented to summarize the scores of the sub-questions into final scores for current and potential environmental impacts, by means of a hierarchy of risk matrices, described as a 'rule-based matrix model' (Holt et al., 2012). An uncertainty score is required for every sub-question and integrated into the models. Finally, two separate versions of the protocols are provided for alien plant pests and for alien plants. These are included in the new computerized version (CAPRA) of the EPPO PRA decision support scheme (EPPO, 2011) and are also available in the weblinks to Appendices 1 and 2. Only a brief description and some examples are provided below.

In both versions, the two main questions are (Q6.08) 'How important is the environmental impact caused by the pest within its current area of invasion?' and (Q6.09) 'How important is the environmental impact likely to be in the PRA area?' Both questions have to be rated according to the five risk levels in the EPPO PRA scheme (minimal, minor, moderate, major, massive). In the first question, the assessor rates the current environmental impact in other invaded regions that can be used as an indicator for determining the potential environmental impact in the PRA area in the second question. If the species to be assessed has not invaded any other area, or if the invasion is too recent and too little is known about its ecology in the invaded areas, this question cannot be answered properly. The assessor may then choose to go directly to Q6.09. He/she may also choose to answer these questions based on well studied closely related species or data for 
the target species from the region of origin, but in this case the assessor is warned that an environmental impact of a pest in its region of origin is often a very poor predictor of potential impact in regions into which it has been introduced. In particular, the absence of any obvious environmental impact in the region of origin should not be considered as a predictor for a low impact in a new area.

The method used to answer Q6.08 is based partly on the 'guidelines for environmental impact assessment and list classification of non-native organisms in Belgium' proposed by Branquart (2007). The pest is assessed through nine sub-questions (eight in the plant version), each referring to impact indicators, organized in three categories of impact: negative impact on native biodiversity ( 3 or 2 sub-questions); alteration of ecosystem processes and patterns (4); and conservation impacts (2). It has been decided not to organize the sub-questions and impact indicators according to ecosystem services (Millennium Ecosystem Assessment, 2005). Firstly, many of these ecosystem services are directly related to social and economic impacts, which are covered by other questions in the EPPO PRA scheme; secondly, impacts on ecosystem services are often more difficult to assess and quantify than impacts on species or ecosystems processes and patterns and, thus, such data are rarely available for alien plant pests and alien plants.

For each of the eight or nine sub-questions, a rating is given based on three choices (low, medium, high). Although the final rating for the main questions is based on five choices, as for all questions in the EPPO PRA scheme, it was felt that providing more than three choices for single impact categories would not be realistic, considering the limited knowledge available on the environmental impact of most alien plant pests and plants. Detailed guidance is provided, for each sub-question, on the meaning of the three scores, and several examples are given for each sub-question and each score. For each answer, an associated uncertainty has to be provided (the possible options being low, medium or high). General guidance is provided on how to score uncertainty. For the final rating of Q6.08, risk and uncertainty scores for each sub-question are combined using a rule-based matrix model, based on the principle that each of the three impact categories is scored with the highest indicator score within its category. The risk matrix model, specific to each question, is based on a series of validation exercises using pests for which the impact is very well known. The use of rule-based matrix models as tool for integrating PRA ratings and uncertainty in the EPPO PRA scheme is detailed in Holt et al. (2012), the only difference being that, in the environmental impact assessment sub-questions with three levels of risk instead of five for the main questions of the EPPO PRA scheme, a score of low, medium or high uncertainty means that the assessors feel they have approximately 94 , 74 or $60 \%$ chance, respectively, of the given score being correct.

Table 1 shows the ratings for Q6.08, assessing the current environmental impact of two plants and three alien plant pests in

Table 1 Impact and uncertainty rating for Question 6.08 'How important is the environmental impact caused by the pest within its current area of invasion?', and its sub-questions, for two alien plants and three plant pests. For the significance of the sub-questions and rating guidance, see Appendices 1 and 2 . Note that eight questions are asked for alien plants and nine for alien plant pests, and that the numbering of the sub-questions is different for plants and plant pests. For plants, subquestions refer to: (01) decline in native species populations and changes in communities of native species; (02) hybridization with native species; (03) physical modifications of habitats; (04) changes to nutrient cycling and availability; (05) modification of natural successions; (06) disruption of trophic and mutualistic interactions; (07) occurrence in habitats of high conservation value; (08) threat to rare or vulnerable species. For plant pests: (01) decline in native species populations; (02) changes in communities of native species; (03) hybridization with native species; (04) physical modifications of habitats; (05) changes to nutrient cycling and availability; (06) modification of natural successions; (07) disruption of trophic and mutualistic interactions; (08) occurrence in habitats of high conservation value; (09) threat to rare or vulnerable species

Species assessed

(invaded region

where impact is

assessed)

Impact rating (Uncertainty rating in parentheses)

\begin{tabular}{|c|c|c|c|c|c|c|c|c|c|c|}
\hline Sub-question & 01 & 02 & 03 & 04 & 05 & 06 & 07 & 08 & 09 & Final \\
\hline \multicolumn{11}{|l|}{ Plants } \\
\hline $\begin{array}{c}\text { Azolla filiculoides } \\
\text { (Lam.) (Europe) }\end{array}$ & $\begin{array}{l}\text { Med. } \\
\text { (Med.) }\end{array}$ & $\begin{array}{l}\text { Low } \\
\text { (Low) }\end{array}$ & $\begin{array}{l}\text { High } \\
\text { (Med.) }\end{array}$ & $\begin{array}{l}\text { Med. } \\
\text { (Low) }\end{array}$ & $\begin{array}{l}\text { Low } \\
\text { (Med.) }\end{array}$ & $\begin{array}{l}\text { High } \\
\text { (High) }\end{array}$ & $\begin{array}{l}\text { Med. } \\
\text { (Med.) }\end{array}$ & $\begin{array}{l}\text { Low } \\
\text { (Low) }\end{array}$ & & $\begin{array}{l}\text { Moderate } \\
\text { (Medium) }\end{array}$ \\
\hline $\begin{array}{l}\text { Prunus serotina } \\
\text { Ehrh. (Europe) }\end{array}$ & $\begin{array}{l}\text { High } \\
\text { (Low) }\end{array}$ & $\begin{array}{l}\text { Low } \\
\text { (Med.) }\end{array}$ & $\begin{array}{l}\text { High } \\
\text { (Low) }\end{array}$ & $\begin{array}{l}\text { Med. } \\
\text { (High) }\end{array}$ & $\begin{array}{l}\text { High } \\
\text { (Low) }\end{array}$ & $\begin{array}{l}\text { Low } \\
\text { (High) }\end{array}$ & $\begin{array}{l}\text { High } \\
\text { (Med.) }\end{array}$ & $\begin{array}{l}\text { Med. } \\
\text { (Med.) }\end{array}$ & & $\begin{array}{l}\text { Massive } \\
\text { (Medium) }\end{array}$ \\
\hline \multicolumn{11}{|l|}{ Plant pests } \\
\hline $\begin{array}{l}\text { Adelges tsugae } \\
\text { (Annand) (Eastern } \\
\text { North America) }\end{array}$ & $\begin{array}{l}\text { High } \\
\text { (Low) }\end{array}$ & $\begin{array}{l}\text { High } \\
\text { (Low) }\end{array}$ & $\begin{array}{l}\text { Low } \\
\text { (Low) }\end{array}$ & $\begin{array}{l}\text { High } \\
\text { (Low) }\end{array}$ & $\begin{array}{l}\text { High } \\
\text { (Low) }\end{array}$ & $\begin{array}{l}\text { High } \\
\text { (Low) }\end{array}$ & $\begin{array}{l}\text { High } \\
\text { (Low) }\end{array}$ & $\begin{array}{l}\text { High } \\
\text { (Low) }\end{array}$ & $\begin{array}{l}\text { High } \\
\text { (Low) }\end{array}$ & $\begin{array}{l}\text { Massive } \\
\text { (Low) }\end{array}$ \\
\hline $\begin{array}{l}\text { Lymantria dispar (L.) } \\
\text { (Eastern North America) }\end{array}$ & $\begin{array}{l}\text { Med. } \\
\text { (Low) }\end{array}$ & $\begin{array}{l}\text { Med. } \\
\text { (Low) }\end{array}$ & $\begin{array}{l}\text { Low } \\
\text { (Low) }\end{array}$ & $\begin{array}{l}\text { Med. } \\
\text { (Low) }\end{array}$ & $\begin{array}{l}\text { Med. } \\
\text { (Low) }\end{array}$ & $\begin{array}{l}\text { Med. } \\
\text { (Low) }\end{array}$ & $\begin{array}{l}\text { Med. } \\
\text { (Low) }\end{array}$ & $\begin{array}{l}\text { High } \\
\text { (Low) }\end{array}$ & $\begin{array}{l}\text { Med. } \\
\text { (Med.) }\end{array}$ & $\begin{array}{l}\text { Moderate } \\
\text { (Low) }\end{array}$ \\
\hline $\begin{array}{l}\text { Diabrotica virgifera } \\
\text { virgifera Le Conte } \\
\text { (Eastern Europe) }\end{array}$ & $\begin{array}{l}\text { Low } \\
\text { (Low) }\end{array}$ & $\begin{array}{l}\text { Low } \\
\text { (Low) }\end{array}$ & $\begin{array}{l}\text { Low } \\
\text { (Low) }\end{array}$ & $\begin{array}{l}\text { Low } \\
\text { (Low) }\end{array}$ & $\begin{array}{l}\text { Low } \\
\text { (Low) }\end{array}$ & $\begin{array}{l}\text { Low } \\
\text { (Low) }\end{array}$ & $\begin{array}{l}\text { Low } \\
\text { (Low) }\end{array}$ & $\begin{array}{l}\text { Low } \\
\text { (Low) }\end{array}$ & $\begin{array}{l}\text { Low } \\
\text { (Low) }\end{array}$ & $\begin{array}{l}\text { Minimal } \\
\text { (Low) }\end{array}$ \\
\hline
\end{tabular}




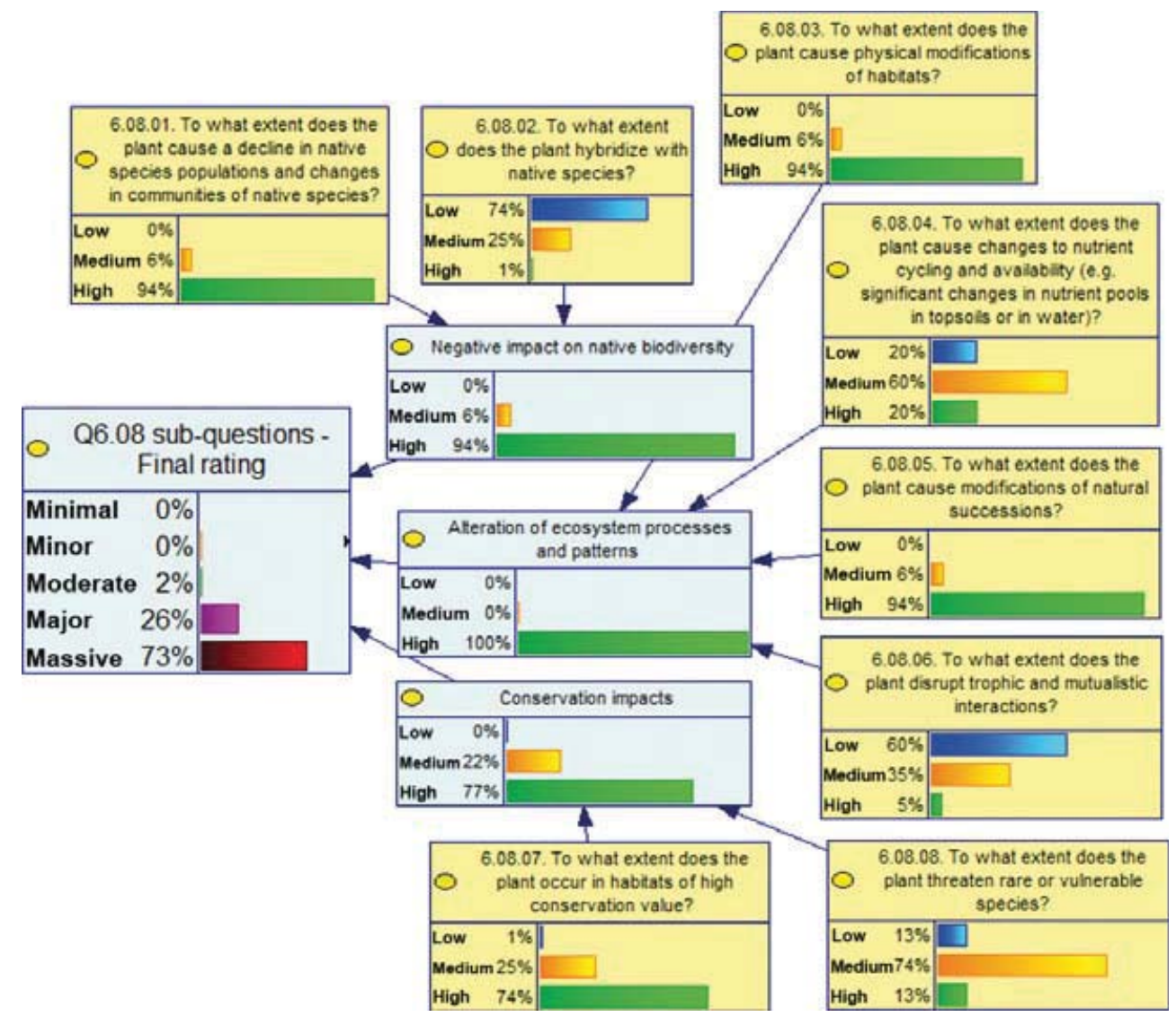

Fig. 1 Rule-based matrix model for Question 6.08 applied to assess the current environmental impact of black cherry, Prunus serotina, in Europe. The model uses a set of predefined distributions of impact magnitude from which the assessors select the most appropriate according to their choice of risk and uncertainty score (Table 1). The selected (modal) score has a frequency of 60, 74 and $94 \%$ for high, medium and low uncertainty, respectively. The frequencies of other scores follow a beta distribution defined by the position and frequency of the model score. For the significance of the sub-questions and rating guidance, see Appendix 2 . For details on the use of rule-based matrix models in the EPPO PRA scheme, see Holt et al. (2012). GeNie2 (2010) was used for the calculations and graphical presentation.

invaded regions, and Fig. 1 shows the rule-based matrix model used to reach the final rating for the current impact of black cherry, Prunus serotina Ehrh., in Europe. It was rated as having a massive impact with medium uncertainty because it is highly invasive in forest ecosystems, having a permanent impact on biodiversity and ecosystems patterns and processes (Starfinger, 1997) In contrast, the impact of the aquatic fern Azolla filiculoides (Lam.) was rated moderate because, although it often forms dense, monospecific mats of floating plants that can affect water ecosystems, these dense populations are usually transient and localized (Branquart et al., 2010). The impact of the hemlock woolly adelgid, Adelges tsugae (Annand), in North America was rated high with low uncertainty because there is published evidence that this Asian insect is threatening entire forest ecosystems in Eastern North America by killing Eastern hemlock (Tsuga canadensis) and the already threatened Carolina hemlock (T. caroliniana) on a large scale (e.g. Jenkins et al., 1999; Weckel et al., 2006). The gypsy moth, Lymantria dispar (L.), is another serious invasive forest pest in North America that may lead to severe tree mortality, particularly in oak (Quercus spp.) stands, and to modification of ecosystem processes (e.g. Lovett et al., 2006). However, in contrast to A. tsugae, L. dispar usually induces only temporary changes to populations and ecosystems and, consequently, its impact has been rated moderate (Table 1). The impact of the third insect assessed in Table 1, the Western corn rootworm, Diabrotica virgifera virgifera Le Conte, was rated minimal because it is purely an agricultural pest in Europe, attacking almost exclusively agricultural crops (Vidal et al., 2005).

The assessment of the potential environmental impact of alien plant pests and plants in the PRA area in Q6.09 starts by asking whether, based on Q6.08, an environmental impact is also likely to occur in the PRA area, and, if yes, at a comparable level based on comparisons of climatic conditions, host plant, habitat, management practices, and threatened organisms and ecosystem functions. If yes, the score of Q6.08 can be given in Q6.09, as an impact in a similar environment will be the most reliable criterion to predict impact in the PRA area. This would, for example, be the case for a PRA for D. virgifera virgifera in the UK, as there is no reason to believe that the environmental impact would be different from that observed in Eastern Europe. If, in contrast, the assessor considers that the situation between the invaded and 
PRA areas is not similar, or if Q6.08 could not be answered, or could be answered only for the native region, or for a closely related species, the following step will depend on whether the assessed organism is a plant pest or a plant. If a plant pest, the potential environmental impact should be assessed using another scoring system, based on impact indicators that are measurable without previous impact studies. Six sub-questions are asked, each referring to impact indicators, and organized in four categories of impact: direct impact on native plants (2 sub-questions); impact on ecosystem patterns and processes (1); conservation impact (2); impact of pesticides (1). As in Q6.08, for each subquestion a rating is given based on three choices (low, medium, high). Detailed guidance is provided for each sub-question on the meaning of these scores, and several examples are given for each sub-question and each score. Uncertainty is assessed as in Q6.08. For the final rating, risk and uncertainty scores of each sub-question are combined using a matrix model, based on a series of validation exercises using pests for which the impact is very well known.

Table 2 shows the ratings for Q6.08, assessing the potential environmental impact of three plant pests in PRA areas. Adelges tsugae, which was considered to have a massive environmental impact in Eastern North America (Table 1), would have a minimal impact in Europe simply because it is specific to Tsuga spp., a genus that is neither native nor widely planted in Europe (Table 2). The Asian longhorned beetle, Anoplophora glabripennis (Motschulsky), is an East Asian species that is presently invading North America and Europe. However, so far, outbreak populations in invaded areas are still under eradication and have been largely contained to urban areas. Therefore, Question 6.08 could not be properly answered. An assessment of its potential environmental impact using the Q6.09 protocol suggests that it is likely to have a massive impact should it become established in Europe, mainly because of its ability to kill a whole range of European tree species, including keystone species (MacLeod et al., 2002). The castniid palm borer, Paysandisia archon (Burmeister), originating from South America, is also difficult to assess using the Q6.08 protocol because it became invasive in Europe only recently, and there is not sufficient information yet on its impact in natural and semi-natural areas. Using the Q6.09 protocol, it is predicted to have a major impact in Europe because of its ability to kill one of the two native European palms, the Mediterranean fan palm, Chamaerops humilis (Lopez-Vaamonde \& Lees, 2010). Furthermore, it is not yet known whether it can affect the second native palm, the threatened Cretan date palm, Phoenix theophrasi.

In an alien plant risk analysis, if the situation regarding environmental impact is likely to be different between the invaded and the PRA areas, the rating of Q6.08 cannot be used for Q6.09. The assessor should then go back to the sub-questions in Q6.08, reassess those sub-questions concerned by the differences, and use the same methodology as described for Q6.08 to obtain a final score for Q6.09. If Q6.08 could not be answered, for example, if the plant has not invaded any other area, or if the invasion is too recent and too little is known about its ecology in the invaded areas, an environmental impact assessment cannot be made properly. Efforts in PRATIQUE failed to develop a simple system for such a situation. So far, PRAs carried out for plants in Europe have been concerned only with plants that have already been reported to be highly invasive or to have an impact, that is, plants for which Q6.08 can definitely be answered. However, in the future PRAs may be performed for species that are just escaping from cultivation and have no invasion and impact history (e.g. Acer rufinerve in Belgium; Branquart et al., 2011). To assess these particular cases, WRAs used in other regions, and designed to screen the potential invasiveness of plants proposed as new introductions or at a very early stage of invasion, can be used (e.g. Williams et al., 2002; Gordon et al., 2010). Recent studies provide further evidence that information related to plant species behaviour and life-history traits in the native range may be used to assess invasiveness (van Kleunen et al., 2010; Schlaepfer et al., 2010), bearing in mind that invasiveness potential and environmental impact are not necessarily correlated (Ricciardi \& Cohen, 2007; Hulme, 2012). As Williams et al. (2002) rightly point out in the conservation WRA system for the New Zealand border, unless a plant is already invasive and having an impact elsewhere, predictions of possible environmental impacts are likely to be highly speculative. Indeed, without this information, WRA analyses discriminate potentially invasive species rather poorly (McGregor et al., 2012).

Table 2 Impact and uncertainty rating for Question 6.09 'How important is the environmental impact likely to be in the PRA area?', and its sub-questions, for three plant pests. For the significance of the sub-questions and rating guidance, see Appendix 1. Sub-questions refer to: (1) risk that the host range of the pest includes native plants in the PRA area; (2) the level of damage likely to be caused by the organism on its major native host plants in the PRA area; (3) the ecological importance of the host plants in the PRA area; (4) the occurrence of the host plants in ecologically sensitive habitats; (5) the risk that the pest would harm rare or vulnerable species; (6) the risk that the presence of the pest would result in an increased and intensive use of pesticides

\begin{tabular}{|c|c|c|c|c|c|c|c|}
\hline Sub-question & 01 & 02 & 03 & 04 & 05 & 06 & Final \\
\hline $\begin{array}{l}\text { Adelges tsugae (Annand) } \\
\text { (Europe) }\end{array}$ & Low (Low) & Low (Low) & Low (Low) & Low (Low) & Low (Low) & Low (Low) & Minimal (Low) \\
\hline $\begin{array}{c}\text { Anoplophora glabripennis } \\
\text { (Motschulsky) (Europe) }\end{array}$ & High (Low) & High (Low) & High (Low) & High (Low) & Medium (Medium) & Low (Medium) & Massive (Low) \\
\hline $\begin{array}{l}\text { Paysandisia archon } \\
\text { (Burmeister) (Europe) }\end{array}$ & High (Low) & High (Low) & Low (Low) & High (Low) & Medium (high) & Medium (Medium) & Major (Medium) \\
\hline
\end{tabular}




\section{Conclusion}

There is no doubt that the assessment of potential environmental impact is one of the most difficult stages in a PRA. It is a fundamentally uncertain process that relies heavily on expert opinion and, given the slow progress in the understanding of impact mechanisms and of traits and factors related to environmental impact, it is likely to remain so in the years to come. Nevertheless, our assessment protocols show that experts may be guided in their decisions by rather simple questions, explicit examples and rating systems. So far, providing guidance and examples represents the most efficient and practical way to effectively guide the completion of assessments aimed at considering whether a species may represent a risk. The two schemes presented here have already been validated in the framework of PRA panels and other working groups, using various cases of well studied alien plant pests and plants. These validation tests showed that the schemes provide assessments that match experts' opinions but, above all, significantly increase consistency among experts' judgements.

Although the methods have been developed primarily for inclusion into the EPPO PRA decision-support scheme, they could be adapted to other PRA schemes. Furthermore, the set of sub-questions related to the first question on impacts in the current area of invasion may also be used as an assessment procedure to assign alien species to black lists or to prioritize species for management decisions (e.g. Branquart, 2007; Brunel et al., 2010). An adapted version of this protocol has been used to define a black list of alien animals in Switzerland (Kenis \& Bacher, 2010).

\section{Acknowledgements}

The authors thank many colleagues from the PRATIQUE project, various panels and working groups for their useful comments on the protocols. PRATIQUE was funded by the European Union 7th Framework Programme Grant No. 212459. M. Kenis and S. Bacher were funded, in an initial phase, by a project from the Swiss Federal Office for the Environment (05.0040.PZ/H451-0585). P. Pyšek was supported by long-term research plan no. AV0Z60050516 and Praemium Academiae award from the Academy of Sciences of the Czech Republic.

\section{Nouveaux protocoles pour évaluer l'impact environnemental d'organismes exotiques dans le schéma OEPP d'aide à la décision pour l'Analyse du Risque Phytosanitaire.}

Evaluer l'impact environnemental potentiel de plantes et ravageurs exotiques est notoirement difficile. De nouveaux protocoles ont été développés dans le cadre du projet européen du $7^{\text {ème }}$ programme-cadre PRATIQUE pour aider à l'évaluation de l'impact environnemental dans le schéma OEPP d'aide à la décision pour l'Analyse du Risque Phytosanitaire (ARP), et améliorer la cohérence entre les évaluateurs et entre les ARP. Les protocoles se composent de séquences de questions, d'instructions et d'exem- ples pour aider à répondre à ces questions. Les scores individuels sont agrégés pour obtenir des scores finaux définissant l'impact environnemental actuel et potentiel de l'organisme évalué, grâce à un ensemble de matrices de risque. Deux protocoles différents sont proposés pour les plantes et les ravageurs. Ces protocoles pourraient aussi être utilisés pour évaluer l'impact environnemental d'organismes exotiques dans d'autres schémas ARP ou pour établir des listes noires ou de priorisation.

\section{Новые протоколы, позволяющие оценивать воздействие вредных организмов на окружающую среду, заложенные в Схему поддержки принятия решений ЕОКЗР, применяемые при анализе фитосанитарного риска}

Трудность оценки потенциального воздействия чужеродных растений и вредных для растений организмов на окружающую среду общеизвестна. Разработанные в рамках проекта 7-ой программы Европейского Союза «PRATIQUE» новые протоколы дают руководство по оценке воздействия на окружающую среду в Схеме поддержки принятия решений при анализе фитосанитарного риска ЕОКЗР. Они позволяют повысить последовательность при выработке разными экспертами оценок и рейтингов риска для различных вредных организмов. В статье приводится ряд вопросов вместе с руководством по определению рейтингов, а также конкретные примеры. Индивидуальные рейтинги сводятся в итоговые с использованием иерархии матриц риска, чтобы можно было оценить текущие и потенциальные воздействия на окружающую среду. Два отдельных протокола созданы для чужеродных растений и для прочих вредных организмов. Эти протоколы могут также использоваться для оценки воздействия на окружающую среду в других схемах АФР, а также для включения чужеродных видов в региональные «черные» списки или для приоритизации видов при принятии решений по управлению.

\section{References}

Baker R, Battisti A, Bremmer J, Kenis M, Mumford J, Petter F, Schrader G, Bacher S, De Barro P, Hulme PE, Karadjova O, Oude Lansink AO, Pruvost O, Pyšek P, Roques A, Baranchikov Y \& Sun J-H (2009) PRATIQUE: A research project to enhance pest risk analysis techniques in the European Union. Bulletin OEPP/EPPO Bulletin 39, 87-93.

Biosecurity Australia (2007) Import Risk Analysis 2007. Biosecurity Australia, Canberra (AUS).

Biosecurity New Zealand (2006) Risk Analysis Procedures, Version 1. Biosecurity New Zealand, (NZ).

Branquart E (ed.) (2007) Guidelines for environmental impact assessment and list classification of non-native organisms in Belgium. http://ias.biodiversity. be/ias/documents/ISEIA_protocol.pdf [accessed on 2 December 2011].

Branquart E, Stiers I, Triest L, Vanderhoeven S, Van Landuyt W, Van Rossum F \& Verloove F (2010) Harmonia database: Azolla filiculoides. Harmonia version 1.2, Belgian Forum on Invasive Species. http://ias.biodiversity.be [accessed on 30th November 2011]. 
Branquart E, Dupriez P, Vanderhoeven S, Van Landuyt W, Van Rossum F \& Verloove F (2011) Harmonia database: Acer rufinerve. Harmonia version 1.2, Belgian Forum on Invasive Species. http://ias.biodiversity.be [accessed on 30th November 2011].

Brunel S, Branquart E, Fried G, van Valkenburg Y, Brundu G, Starfinger U, Buholzer S, Uludag A, Joseffson M \& Baker R (2010) EPPO prioritization process for invasive alien plants. Bulletin OEPP/EPPO Bulletin 40, 407422.

Daehler CC, Denslow JS, Ansari S \& Kuo H (2004) A risk-assessment system for screening out invasive pest plants from Hawaii and other Pacific Islands. Conservation Biology 18, 360-368.

Desprez-Loustau M-L, Robin C, Buée M, Courtecuisse R, Garbaye J, Suffert J, Sache I \& Rizzo DM (2007) The fungal dimension of biological invasions. Trends in Ecology and Evolution 22, 472-480.

EPPO (2007). Guidelines on Pest Risk Analysis; Decision support scheme for quarantine pests, EPPO standard PM 5/3 (3).

EPPO (2011) Guidelines on Pest Risk Analysis; Decision support scheme for quarantine pests. http://archives.eppo.org/EPPOStandards/pra.htm [accessed on 01 March 2012]

FAO (2004) Pest risk analysis for quarantine pests including analysis of environmental risks and living modified organisms, ISPM 11. International Plant Protection Convention, FAO, Rome (IT).

FAO (2007). Framework for pest risk analysis, ISPM 2. International Plant Protection Convention. FAO, Rome (IT)

FAO (2010). Guidelines on the understanding of potential economic importance and related terms including reference to environmental considerations. Supplement 2. ISPM 5. International Plant Protection Convention. FAO, Rome (IT).

GeNie2 (2010) Decision Systems Laboratory, University of Pittsburgh. http:// genie.sis.pitt.edu/ [accessed on 2 December 2011]

Gordon DR, Riddle B, Pheloung P, Ansari S, Buddenhagen C, Chimera C, Daehler CC, Dawson W, Denslow JS, Jaqualine TN, LaRosa A, Nishida T, Onderdonk DA, Panetta FD, Pyšek P, Randall RP, Richardson DM, Virtue JG \& Williams PA (2010) Guidance for addressing the Australian Weed Risk Assessment questions. Plant Protection Quarterly 25, 56-74.

Holt J, Leach AW, Knight JD, Griessinger D, MacLeod A, van der Gaag DJ, Schrader G \& Mumford GD (2012) Tools for visualising and integrating Pest Risk Assessment ratings and uncertainties. Bulletin OEPP/EPPO Bulletin 42, 35-41 (This issue).

Hulme PE (2012) Weed risk assessment: a way forward or a waste of time? Journal of Applied Ecology 49, 10-19.

Jenkins JC, Aber JD \& Canham CD (1999) Hemlock woolly adelgid impacts on community structure and $\mathrm{N}$ cycling rates in eastern hemlock forests. Canadian Journal of Forest Research 29, 630-645.

Kenis M \& Bacher S (2010) Building a black list and a watch list for alien animals in Switzerland. Unpublished report for the Swiss Federal Office for the Environment.

Kenis M, Auger-Rozenberg M-A, Roques A, Timms L, Péré C, Cock MJW, Settele J, Augustin S \& Lopez-Vaamonde C (2009) Ecological effects of invasive alien insects. Biological Invasions 11, 21-45.

Levine JM, Vilà M, D’Antonio CM, Dukes JS, Grigulis K \& Lavorel S (2003) Mechanisms underlying the impact of exotic plant invasions. Philosophical Transactiuons of the Royal Society B 270, 775-781.

Lopez-Vaamonde C \& Lees D (2010) Paysandisia archon (Burmeister, 1879) the castniid palm borer (Lepidoptera, Castniidae). In: Alien Terrestrial Arthropods of Europe (eds Roques A, Kenis M, Lees D, Lopez-Vaamonde C, Rabitsch W, Rasplus J-Y \& Roy DB), BIORISK - Biodiversity and Ecosystem Risk Assessment (Special Issue) 4, 990-991.

Lovett GM, Canham CD, Arthur MA, Weathers KC \& Fitzhugh RD (2006) Forest ecosystem responses to exotic pests and pathogens in eastern North America. BioScience 56, 395-405.

MacLeod A, Evans HF \& Baker RHA (2002) An analysis of pest risk from an Asian longhorn beetle (Anoplophora glabripennis) to hard wood trees in the European community. Crop Protection 21, 635-645.
McGregor KF, Watt MS, Hulme PE \& Duncan RP (2012) How robust is the Australian weed risk assessment protocol? A test using pine invasions in the Northern and Southern Hemisphere. Biological Invasions Online First. doi: 10.1007/s10530-011-0133-5.

Millennium Ecosystem Assessment (2005). Ecosystems and Human WellBeing: Synthesis. Island Press, Washington (USA).

Parker IM, Simberloff D, Lonsdale WM, Goodell K, Wonham M, Kareiva PM, Williamson MH, Von Holle B, Moyle PB, Byer JE \& Goldwasser L (1999) Impact: toward a framework for understanding the ecological effects of invaders. Biological Invasions 1, 3-19.

Pheloung PC, Williams PA \& Halloy SR (1999) A weed risk assessment model for use as a biosecurity tool evaluating plant introductions. Journal of Environmental Management 57, 239-251.

Ricciardi A \& Cohen J (2007) The invasiveness of an introduced species does not predict its impact. Biological Invasions 9, 309-315.

Richardson DM, Pyšek P, Rejmánek M, Barbour MG, Panetta FD \& West CJ (2000) Naturalization and invasion of alien plants: concepts and definitions. Diversity and Distributions 6, 93-107.

Soliman T, van der Werf W, Mourits M \& Oude Lansink A (2010) Economic impact assessment in pest risk analysis. Crop Protection 29, 517-524.

Schlaepfer DR, Glättli M, Fischer M \& van Kleunen M (2010) A multi-species experiment in their native range indicates pre-adaptation of invasive alien plant species. New Phytologist 185, 1087-1099.

Starfinger U (1997). Introduction and naturalization of Prunus serotina in Central Europe. In: Plant Invasions: Ecological Mechanisms and Human Responses (eds Starfinger U, Edwards K, Kowarik I. \& Williamson M), pp. 161-171. Backhuys, Leiden (NL).

USDA-APHIS (2000) Guidelines for Pathway-initiated Pest Risk Assessments, version 5.02. US Department of Agriculture, Animal and Plant Health Inspection Service. Plant Protection and Quarantine, Riverdale, MD (USA).

van Kleunen M, Weber E \& Fischer M (2010) A meta-analysis of trait differences between invasive and non-invasive plant species. Ecology Letters 13, 235-245.

Vidal S, Kuhlmann U \& Edwards CR (eds) (2005) Western Corn Rootworm: Ecology and Management. CABI Publishing, Wallingford (UK).

Vilà M, Basnou C, Pyšek P, Josefsson M, Genovesi P, Gollasch S, Nentwig W, Olenin S, Roques A, Roy D \& Hulme PE \& DAISIE partners (2010) How well do we understand the impacts of alien species on ecosystem services? A pan-European cross-taxa assessment. Frontiers in Ecology and the Environment 8, 135-144.

Vilà M, Espinar JL, Hejda M, Hulme PE, Jarosik V, Maron JL, Pergl J, Schaffner U, Sun Y \& Pysek P (2011) Ecological impacts of invasive alien plants: a meta-analysis of their effects on species, communities and ecosystems. Ecology Letters 14, 702-708.

Weckel M, Tirpak JM, Nagy C \& Christie R (2006) Structural and compositional change in an old-growth Eastern hemlock Tsuga canadensis forest, 1965-2004. Forest Ecology and Management 231, 114-118.

Williams PA, Wilton A \& Spencer N (2002) A proposed conservation weed risk assessment system for the New Zealand border. Science for Conservation 208, 1-47.

Williamson M (1996) Biological Invasions. Population and Community Biology Series, 15. Chapman \& Hall, London (UK).

\section{Appendices 1 and 2}

Appendix 1 (Revision of the questions on the environmental impact of the EPPO PRA scheme, version for plant pests) and Appendix 2 (Revision of the questions on the environmental impact of the EPPO PRA scheme, version for plants) are available as supporting information. This information may be found at: http://archives.eppo.int/files/pratique_42_1/kenis_app1. doc and http://archives.eppo.int/files/pratique_42_1/kenis_app2. doc respectively. 